\title{
Plasma Kallikrein
}

National Cancer Institute

\section{Source}

National Cancer Institute. Plasma Kallikrein. NCI Thesaurus. Code C95409.

Plasma kallikrein (638 aa, $71 \mathrm{kDa}$ ) is encoded by the human KLKB1 gene. This protein plays a role in the mediation of proteolysis. 